\title{
The Use of Two Novel Maleanilinic Acid Indicators in Ground Water Analyses Applying UV-Vis Spectra and Atomic Spectrometry and Biological Studies of These Derivatives
}

\author{
Mohamed A. Zayed ${ }^{1 *}$ and Azza A. Eladly ${ }^{2}$ \\ ${ }^{1}$ Chemistry Department, Faculty of Science, Cairo University, Giza-12613, Egypt. \\ ${ }^{2}$ Science and Technology Center of Excellence, Military Production, P. O. Box 3066, \\ Elsalam II, Cairo, Egypt.
}

\begin{abstract}
TN THE PRESENT work novel para methyl, para methoxy maleanilinic acid derivatives; which were prepared by solvent free reaction between maleic anhydride and p- methyl and p- methoxy aniline derivatives in a good yield. The prepared two novel derivatives are successfully applied in this research as selective chromogenic analytes for spectrophotometric analysis of heavy metal cations in water samples. Simple, accurate, precise, sensitive and $\mathrm{pH}$-selective visible spectrophotometric method has been developed and validated for the direct determination of iron (III) and chromium (III) in pure and/ or environmental samples. These selected indicators are successfully applied for the analysis of $\mathrm{Fe}$ (III) and $\mathrm{Cr}$ (III) in water samples collected from regional wells in El-Beheira governorate. The obtained results are compared with the data obtained by atomic absorption of these metal cations in the same wells; which indicate great correlation between the two techniques. This correlation refers to the validation of the suggested spectrophotometric procedures in environmental analysis. These indicators are also tested against some kinds of bacteria, fungi and cancer cells. These derivatives possess great activities towards different kinds of bacteria and cancer cells. The obtained results in this research indicate that; the two prepared novel maleanilic acid derivatives are successfully applied in environmental analyses and health applications.
\end{abstract}

Keywords: N-maleanilic acid Indicators, Atomic Absorption, Iron (III) Chromium (III), Ground water analysis, Health applications.

\section{Introduction}

Metal ions play a very important role in many biological systems [1]. Iron is considered as second most abundant metal in the earth's crust. Dissolved iron in water, causes the water to taste metallic [2]. Therefore, it is vital for both animals and plants. Its versatility is unique. It is found in such diverse metallo-enzyme as nitrogenase, various oxidases, hydrogenases, reductases, dehydrogenases, deoxygenases, and dehydrases. Iron is involved in enormous range of function and the whole range of life forms, from bacteria to man [3]. Owing to cheapness, rapidity, and simplicity of UV-Visible spectrophotometric methods; they have been developed for the determination of metal ions [4-8]. It involved the use of various chromogenic analytes for this purpose [9-11]. Ferric is the most stable state of iron in the solutions; hence the determination of iron is generally demonstrated on $\mathrm{Fe}$ (III) contents. Spectrophotometry is essentially a trace analysis technique and is one of the most powerful tools in chemical analyses [12-14]. However, iron concentrations in body tissue must be carefully regulated; because excessive iron leads to tissue damage as a result of the formation of free radicals [15]. Elemental iron is rarely found in nature, as the iron ions $\mathrm{Fe}$ (II) and Fe (III) readily combine with oxygen and sulfur; which containing compounds to form oxides, hydroxides, carbonates, and sulfides. So the dissolved iron more commonly exists in the form of its oxides [16]. In order to provide safe drinking water to the public, both government and private organizations measure iron content in drinking water and other tap waters in every sector including schools, hospitals, industries, etc. [17]. Important research had been reported simple and reliable method for the extraction,

*Corresponding author e-mail: mazayed429@yahoo.com, Tel: 002-01005776675

DOI: 10.21608/EJCHEM.2018.4387.1391

C2017 National Information and Documentation Center (NIDOC) 
separation, preconcentration, and determination of iron as its bathophenanthroline complex by the use of octadecylsilica membrane disks and spectrophotometry. Chromium is a major pollutant for environment, and exists mainly in two different oxidation states in the environment, $\mathrm{Cr}$ (III) and $\mathrm{Cr}(\mathrm{VI})$; which have contrasting physiological effects. $\mathrm{Cr}$ (III) is considered as an essential trace element for the maintenance of effective glucose, lipid, and protein metabolism in mammals [18]. The high concentration of chromium cause liver kidney circulatory system effects [19]. In this paper, p-MMA and p-MOMA were prepared [20] and used for determination iron and chromium in pure form and applied in ground water; which is one of the most important sources of water in Egypt [21]. So these ions determined in wells; which are distributed in El-Beheira Governorate villages and previously studied [2224]. These determined by spectrophotometry [25-27] in comparison with atomic absorption measurements. These indicators are tested against some kinds of bacteria, fungi and cancer cells as health applications to confirm their life importance.

\section{Experimental}

Materials and methods of analyses

All chemicals used were of analytical reagent grade (AR) and of highest purity available. Ferric chloride $\left(\mathrm{M} . \mathrm{wt}=162.21 \mathrm{~g} \mathrm{~mol}^{-1}\right)$ and chromium chloride $\left(\mathrm{M} . \mathrm{wt}=266.45 \mathrm{~g} \mathrm{~mol}^{-1}\right)$ were purchased from Win lab. P-Anisidine, 98\% was from Oxford. P-Toluidine, 99\% crystalline and Maleic anhydride, $99 \%$ pellets were from Acros. Chromium and Iron as standards for Atomic Absorption from Fluke; whereas ethanol absolute from Sigma Aldrich.

\section{Preparation of the studied compounds}

In the present work two novel N-maleanilinic acids derivatives namely (E) -4- ((4- methyl phenyl) amino)-4- oxobut-2-enoic acid (p-MMA) and (E) - 4- ((4-methoxy phenyl) amino)-4oxobut-2-enoic acid (p-MOMA); were prepared by solvent free reaction between maleic anhydride and a p-methyl and p-methoxy aniline derivatives in a good yield[19]. The studied compounds have the following proposed structures (Fig. 1).

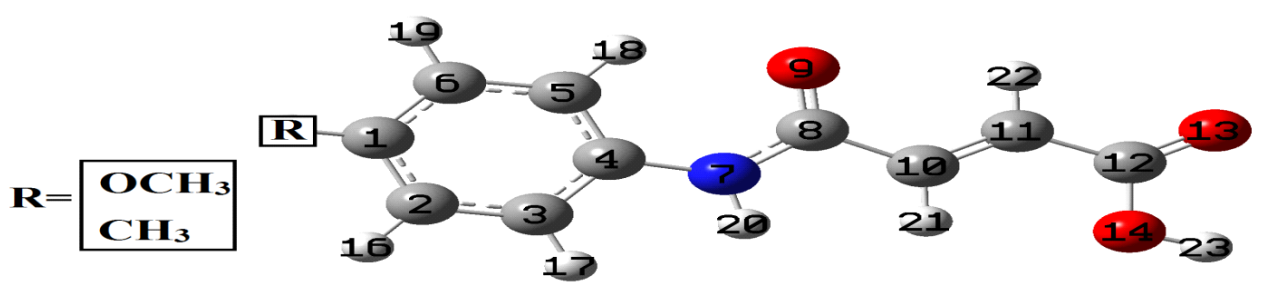

Fig. 1. The optimized structures of derivatives-maleanilinic acid with their numbering system.

\section{Cytotoxicity studies and procedures}

Cytotoxicity studies and procedures are involved the following $[28,29]$.

Mammalian cell lines: MCF-7 cells (human breast cancer cell line), HepG-2 cells (human Hepatocellular carcinoma) and HCT-116 (colon carcinoma) were obtained from VACSERA Tissue Culture Unit.

Chemicals Used: Dimethyl sulfoxide (DMSO), crystal violet and trypan blue dyes were purchased from Sigma St. Louis, Mo., USA. Fetal Bovine serum, DMEM, RPMI-1640, HEPES buffer solution, L-glutamine, gentamycin and $0.25 \%$ Trypsin-EDTA were purchased from Lonza.

Crystal violet stain (1\%): It composed of
$0.5 \mathrm{~g}$ of crystal violet with $50 \mathrm{~mL}$ methanol; which dissolved then made up to volume $100 \mathrm{~mL}$ with double distilled $\mathrm{H}_{2} \mathrm{O}$ and filtered through a Whatmann No.1 filter paper.

Cell line Propagation: The cells were propagated in Dulbecco's modified Eagle's medium (DMEM) supplemented with 10\% heatinactivated fetal bovine serum, 1\% L-glutamine, HEPES buffer and $50 \mu \mathrm{g} / \mathrm{mL}$ gentamycin. All cells were maintained at $37^{\circ} \mathrm{C}$ in a humidified atmosphere with $5 \% \mathrm{CO}_{2}$ and were subcultured two times a week.

\section{Instruments}

The thermo spectronic Nicolet evolution300BB UV-Visible spectrophotometer was used for absorbance values measurements in the wavelength range $190-900 \mathrm{~nm}$. 
Weights measurement was performed by using sensitive analytical balance of $0.0001 \mathrm{~g}$ max $120 \mathrm{~g}$ $\mathrm{d}=0.1 \mathrm{mg}$, Shimadzu model.

Stirring and heating were performed by using magnetic stirrer made in Europe, hot plate (VELPmade in UK).

The $\mathrm{pH}$ values were measured using $\mathrm{pH}$ meter, ORION Triode model 420A with $\mathrm{Ag} / \mathrm{AgCl}$ internal reference system of thermistor for ATC, model 915BN. The instrument is calibrated using standard buffer solution, 4.00, 7.00 and 10.00 before direct measurement. Micro-Accupipette, USA $(100-1000) \mu \mathrm{L}$ was used to measure the very small volumes, whereas glass pipettes $(2,5$ $\mathrm{mL}$ ) were used to measure the large volumes.

\section{Solutions and procedures}

Stock solutions $0.1 \mathrm{M}$ of p-MMA and p-MOMA were prepared by dissolving 2.05 and $2.21 \mathrm{~g}$ respectively in $15 \mathrm{~mL}$ ethanol; then completed to $100 \mathrm{~mL}$ in measuring flask.

Stock $0.1 \mathrm{M}$ solutions of ferric chloride and chromium chloride were prepared by dissolving 1.62 and $2.66 \mathrm{~g}$ in least amount of dilute $\mathrm{HCl}$ and bi-distilled water; then completed to $100 \mathrm{~mL}$ in measuring flask.

Series of universal buffer solutions covering the range of $\mathrm{pH}$ values from 2.00 to 11.05 were prepared as recommended by Britton [30].

\section{Stoichiometric ratio}

Continuous variation method (CVM) and molar ratio method (MRM) [31, 32] were applied to determine the suitable stoichiometric ratio reactants (indicators: analytes). In CVM, a series of solutions were prepared by adding different volumes of (iron and chromium) to different volumes of indicators so that the total number of moles was kept constant. In case of p-MMA $1-8 \mathrm{~mL}$ of $0.1 \mathrm{M}$ were added to $8-1 \mathrm{~mL}$ of 0.1 $\mathrm{M}$ analytes and the volume was completed to 10 $\mathrm{mL}$ with buffer solution. The spectrophotometric measurements of these solutions were recorded at $522 \mathrm{~nm}$, time $=5 \mathrm{~min}, \mathrm{pH}=4.72$ and $70 \pm 1$ ${ }^{\circ} \mathrm{C}$. In case of p-MOMA the same additions were done and the spectrophotometric measurements of these solutions were recorded at $530 \mathrm{~nm}$, time $=15 \mathrm{~min}, \mathrm{pH}=6.75$ and $60^{\circ} \mathrm{C}$. In MRM; to $4 \mathrm{~mL}$ of $0.1 \mathrm{M}$ p-MMA or p-MOMA solutions, $0.5-6$ $\mathrm{mL}$ of $0.1 \mathrm{M}$ of iron (III) or $\mathrm{Cr}$ (III) were added and $1 \mathrm{~mL}$ buffer solution then completed to $10 \mathrm{~mL}$ distilled water. The spectra of these mixtures were measured at $522 \mathrm{~nm}$, time $=5 \mathrm{~min}, \mathrm{pH}=4.72$ and
$70 \pm 1{ }^{\circ} \mathrm{C}$ for p-MMA; and for p-MOMA at 530 $\mathrm{nm}$, time $=15 \mathrm{~min}, \mathrm{pH}=6.75$ and $60^{\circ} \mathrm{C}$.

\section{Calibration curve}

The calibration curves were constructed by adding variable amounts of iron and chromium analytes $(0.5-4.0 \mathrm{~mL}$ of $0.1 \mathrm{M})$ to constant concentration of $4 \mathrm{~mL}$ of $0.1 \mathrm{M}$ p-MMA or p-MOMA and the volume of each mixture was completed in a measuring flask to $10 \mathrm{~mL}$. The absorbance values of mixtures obtained were measured under the selected proper conditions. Analytical parameters determined for the microdetermination of $\mathrm{Fe}$ (III) and $\mathrm{Cr}$ (III) included molar absorptivity $(\varepsilon)$, Sandell sensitivity (S.S), standard and relative standard deviations (SD and RSD), limit of detection (LOD), limit of quantification (LOQ) and recovery $\%$ for indicators.

\section{Study of interferences}

To determine the selectivity of the applied procedures, the solutions of cations under test containing $\mathrm{Cr}$ (VI) and $\mathrm{Fe}$ (II) were prepared ( $4.0 \mathrm{~mL}$ of $0.1 \mathrm{M}$ ) of $\mathrm{Fe}$ (III) and $\mathrm{Cr}$ (III) ) to constant concentration of $4 \mathrm{~mL}$ of $0.1 \mathrm{M} \mathrm{p}-\mathrm{MMA}$ or p-MOMA and $(1.0 \mathrm{~mL}$ of $0.1 \mathrm{M})$ of $\mathrm{Cr}$ (VI) and Fe (II). The volume of each mixture was completed in a measuring flask to $10 \mathrm{~mL}$. Then these are analyzed under proper conditions.

\section{Collected water samples and its locations}

The analyzed water samples were collected from groundwater wells from some villages in Kom Hamada City in the El-Beheira Governorate. The geographical location of Al- Beheira governorate is given in Fig. 2.

The wells locations are mentioned in Table 1.

The collection of valid samples is the vital first step [33]. In this process water samples were collected in polyethylene bottles. Firstly, the bottles were soaked in nitric acid solution for 24 hours and kept at room temperature. These were rinsed three times with deionized water; then water samples were preserved and transported to the laboratory in ice boxes. Water samples were acidified with nitric acid solution $(\mathrm{pH}<2)$ and stored in a refrigerator. Filtration to remove suspended materials; which could dissolve when acid, is added. Sampling should be done with the same care as the analysis in order for the data to be meaningful, sampling must carried out with a clear purpose and with understanding of the problem and the physical condition that exist. 


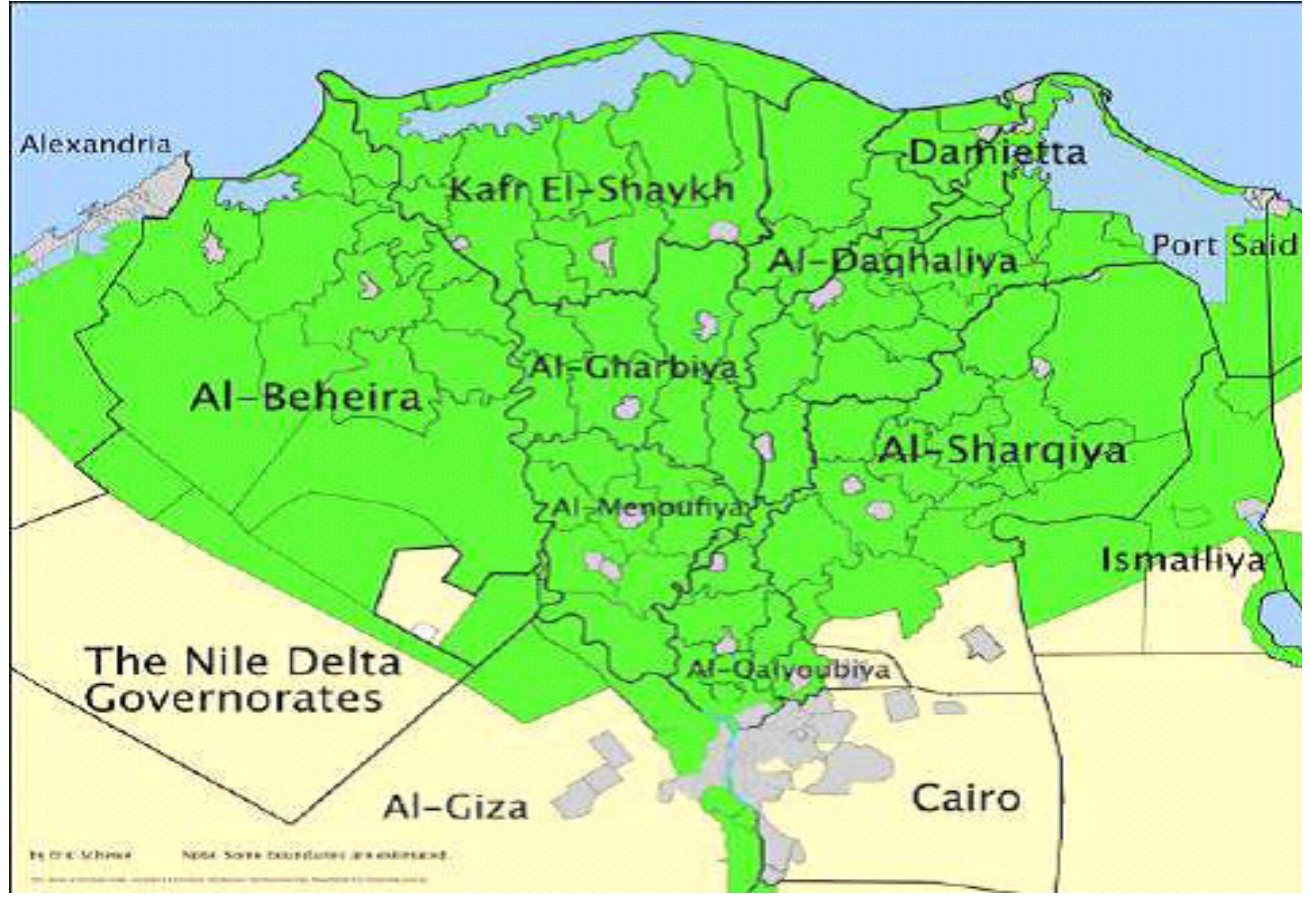

Fig. 2. The geographical location of Al- Beheira governorate.

TABLE 1. Samples locations and its description.

\begin{tabular}{lll}
\hline Well number & Name of location & Wells Description \\
\hline 1 & Village of Mughneen & From well (2) \\
2 & Village of El-Hadain & From well (1) \\
3 & Village of El-Toud & From well (2) \\
4 & Village of Kherbita & From well (1) \\
5 & Village of Zawiat Albahar & From well (2) \\
6 & Village of Ntma & From well (1) \\
7 & Village of Zawiat Albahar & From well (1) \\
8 & Village of El-Toud & From well (1) \\
9 & Village of Mughneen & From well (3) \\
\hline
\end{tabular}

Samples were being filtered using filtration system through $0.45 \mu \mathrm{m}$-pore-diameter filter paper; then analyzed for iron and chromium using atomic absorption spectrophotometer, model AA.6300 SHIMADZU with an air-acetylene flame. The operating conditions of instrument are presented in Table 2.

Application of suggested procedures to analysis of wells water samples

For determination of Fe (III) in $4 \mathrm{~mL}$ of wells water samples; $4 \mathrm{~mL}$ of $0.1 \mathrm{p}$-MMA or p-MOMA indicator were added followed by $1 \mathrm{~mL}$ buffer solution then completed to $10 \mathrm{~mL}$ distilled water. These samples were measured at proper conditions by spectrophotometric and by atomic absorption. The chromium analysis in wells water samples; due the low concentration of $\mathrm{Cr}$ (III) in these samples; 1-5 mL standard chromium of $0.1 \mathrm{M}$ were added and followed by $4 \mathrm{~mL}$ of 0.1 M p-MMA or p-MOMA indicators and followed by $1 \mathrm{~mL}$ buffer solution then completed to $10 \mathrm{~mL}$ distilled water. These samples were measured at proper conditions by spectrophotometric and by atomic absorption. These water samples were also checked for iron (III) and chromium (III) cations by measurement of their contents using atomic absorption techniques under proper 
selected conditions (Table 2).

In both spectrophotometric analyses and atomic absorption measurements; four samples replicates were used to check accuracy of the applied procedures.

\section{Biological activity studies}

In Microanalytical center at Cairo University; the antimicrobial activities of tested compounds were determined by means of a modified KirbyBauer disc diffusion method [34] under standard conditions using Mueller-Hinton agar medium (tested for composition and $\mathrm{pH}$ ), as described by NCCLS [35]. Plates inoculated with filamentous fungi as Aspergillus flavus at $25^{\circ} \mathrm{C}$ for 48 hours; Gram (+) bacteria as Staphylococcus aureus, Bacillus subtilis; Gram (-) bacteria as Escherichia coli, Pseudomonas aeuroginosa they were incubated at $35-37^{\circ} \mathrm{C}$ for $24-48$ hours and yeast as Candida albicans incubated at $30^{\circ} \mathrm{C}$ for $24-48$ hours and, then the diameters of the inhibition zones were measured in millimeter [36].

In present work, the test for p-MMA or

TABLE 2. Atomic Absorption Instrumental Conditions.

\begin{tabular}{lccccc}
\hline Element & $\begin{array}{c}\text { Wave length } \\
(\mathbf{n m})\end{array}$ & $\begin{array}{c}\text { Slit width } \\
(\mathbf{n m})\end{array}$ & $\begin{array}{c}\text { Lighting } \\
\text { mode }\end{array}$ & Flame & Standards (mg/L) \\
\hline $\mathrm{Fe}$ & 248.3 & 0.2 & ${\mathrm{BGC}-\mathrm{D}_{2}}$ & Air-actylene & $0.5,1.0,2.0$ \\
$\mathrm{Cr}$ & 357.9 & 0.5 & ${\mathrm{BGC}-\mathrm{D}_{2}}_{2}$ & Air-actylene & $0.5,1.0,2.0$ \\
\hline
\end{tabular}

p-MOMA was done using the diffusion agar technique. Spore suspension $\left(0.5 \mathrm{~mL}, 10^{-6}-10^{-7}\right.$ spore $\left.\mathrm{mL}^{-1}\right)$ of each of the investigated organism was added to a sterile agar medium just before solidification, then poured into sterile Petri dishes (9 $\mathrm{cm}$ in diameter) and left to solidify. Using sterile cork borer (6 $\mathrm{mm}$ in diameter), three holes (wells) were made into each dish, and then 0.1 $\mathrm{mL}$ of the test compound dissolved in DMF (100 $\mathrm{mg} \mathrm{mL}^{-1}$ ) was poured into these holes. The dishes were incubated at $37{ }^{\circ} \mathrm{C}$ for $48 \mathrm{~h}$ where clear or inhibition zones were detected round each hole. DMF $(0.1 \mathrm{~mL})$ was used as control under the same conditions. By subtracting the diameter of the inhibition zone resulting with DMF from that obtained from each indicator, antibacterial activities were calculated [37].

\section{Cytotoxicity studies}

Cytotoxicity evaluation using viability assay: The cells were seeded in 96-well plate at a cell concentration of $1 \times 10^{4}$ cells per well in $100 \mu \mathrm{L}$ of growth medium. Fresh medium containing different concentrations of the test sample was added after $24 \mathrm{~h}$ of seeding. Serial two-fold dilutions of the tested chemical compound were added to confluent cell monolayers dispensed into 96-well, flat-bottomed microliter plates Falcon, NJ, USA using a multichannel pipette. The microtiter plates were incubated at $37^{\circ} \mathrm{C}$ in a humidified incubator with $5 \% \mathrm{CO}_{2}$ for a period of $48 \mathrm{~h}$. Three wells were used for each concentration of the test sample. Control cells were incubated without test sample and with or without DMSO. The little percentage of DMSO present in the wells (maximal $0.1 \%$ ) was found not to affect the experiment. After incubation of the cells for at $37^{\circ} \mathrm{C}$, various concentrations of sample were added, and the incubation was continued for 24 $\mathrm{h}$ and viable cells yield was determined by a colorimetric method.

In brief, after the end of the incubation period, media were aspirated and the crystal violet solution (1\%) was added to each well for at least 30 minutes. The stain was removed and the plates were rinsed using tap water until all excess stain is removed. Glacial acetic acid (30\%) was then added to all wells and mixed thoroughly, and then the absorbance of the plates was measured after gently shaken on Microplate reader TECAN, Inc., using a test wavelength of $490 \mathrm{~nm}$. All results were corrected for background absorbance detected in wells without added stain. Treated samples were compared with the cell control in the absence of the tested compounds. All experiments were carried out in triplicate. The cell cytotoxic effect of each tested compound was calculated. The optical density was measured with the microplate reader Sun Rise, TECAN, Inc, USA to determine the number of viable cells and the percentage of viability was calculated as [(ODt/ODc) $]$ x $100 \%$; where ODt is the mean optical density of wells treated with the tested sample and ODc is the mean optical density of untreated cells. The relation between surviving cells and drug concentration is 
plotted to get the survival curve of each tumor cell line after treatment with the specified compound. The $50 \%$ inhibitory concentration $\left(\mathrm{IC}_{50}\right)$, the concentration required to cause toxic effects in $50 \%$ of intact cells, was estimated from graphic plots of the dose response curve for each conc. using Graphpad Prism software San Diego, CA. USA.

\section{Results and Discussion}

Spectrophotometric study of reaction between $\mathrm{Fe}$ (III) and $\mathrm{Cr}$ (III) and p-MMA and p-MOMA analytes

The spectra of the reaction product between $\mathrm{Fe}$ (III) and p-MMA or p-MOMA in aqueous medium gives red color; whereas the spectra of the reaction of $\mathrm{Cr}$ (III) with the same indicators gives dark green color under proper conditions of temperature, time and $\mathrm{pH}$. These products in solutions are scanned in the wavelength range $190-900 \mathrm{~nm}$ and the obtained results are given in Fig. 3.

The spectra in Fig. 3 refer to maximum absorption at wavelengths of 522, 530, 573 and $405 \mathrm{~nm}$ for Fe and $\mathrm{Cr}$ with p-MMA and p-MOMA respectively; with molar absorptivity values of $\varepsilon=$ $0.71 \mathrm{X}^{2} 0^{2}, 1.75 \times 10^{2}, 0.25 \times 10^{2}$ and $0.90 \times 10^{2}$ $\mathrm{L} \mathrm{mol}{ }^{-1} \mathrm{~cm}^{-1}$. The reaction products are found to be stable for at least 24 hours; $\mathrm{pH}=2$ and 3 for $\mathrm{Cr}$ and $\mathrm{Fe}$ respectively and at temperature $70^{\circ} \mathrm{C}$. Hence, these parameters were used as optimum conditions of the microdetermination of Fe (III) and $\mathrm{Cr}$ (III) cations in wells water samples.
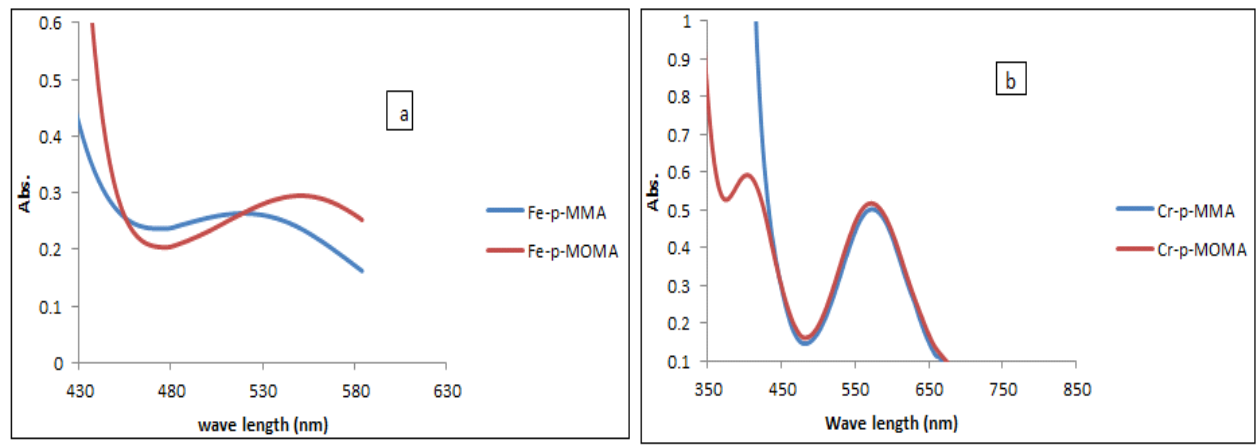

Fig. 3. UV spectrum of reaction product between 5X10-3M Fe (III) and 4X10-2M Cr (III) with indicators at temp. $7^{\circ} \mathrm{C}$ : a- Fe with p-MMA, p-MOMA; b-Cr with p-MМА, p-МOMA.

Stoichiometry between indicators and Fe (III) and $\mathrm{Cr}$ (III) cations

The continuous variation and molar ratio methods [31,32] are used to check the ratio between $\mathrm{Fe}(\mathrm{III})$ and $\mathrm{Cr}$ (III) with different indicators in order to select the optimum conditions for their micro-determination in pure and/ or in water samples. The results of these studies are presented in Fig. 4 and 5.

These results indicate that the reaction takes place in the ratio $1: 1$ for $\mathrm{Fe}$ (III): indicators and 2:1 for $\mathrm{Cr}$ (III): indicators.

\section{Validity of Beer's Law}

The calibration curves of Fe (III) and $\mathrm{Cr}$ (III) by using p-MMA or p-MOMA was constructed at 522, 530, 576 and $405 \mathrm{~nm}$ respectively, under optimum conditions, $\lambda_{\max }$, stoichiometric, $\mathrm{pH}$ (acidic medium), temperature and time. So Beer's Law is obeyed in the concentration range of $81.10-648.84,519.50-2337.75,519.50-3117.00$ and 81.11-648.84 $\mu \mathrm{g} \mathrm{mL}^{-1}$ respectively. Above this limit, negative deviation was observed. The correlation coefficient value was found to be $0.9923,0.9993,0.9903$ and 0.9987 for the study reaction between $\mathrm{Fe}$ (III), $\mathrm{Cr}$ (III) and p-MMA or p-MOMA indicator respectively. Therefore, these data studied to obtain the analytical parameters of the studied reactions between Fe (III), Cr (III) and p-MMA or p-MOMA indicator respectively; which are summarized in Table 3.

The low values of the calculated standard deviation (SD) and relative standard deviation (RSD \%); indicate the high accuracy and precision of the proposed method. This is supported also by the calculated values of Sandell sensitivity; which indicates the high sensitivity of the proposed methods. Finally it is concluded that, the spectrophotometric methods can be successfully applied by using indicators for the determination of $\mathrm{Fe}$ (III) and $\mathrm{Cr}$ (III) in pure and/ or in wells water samples, with high accuracy, precision and 

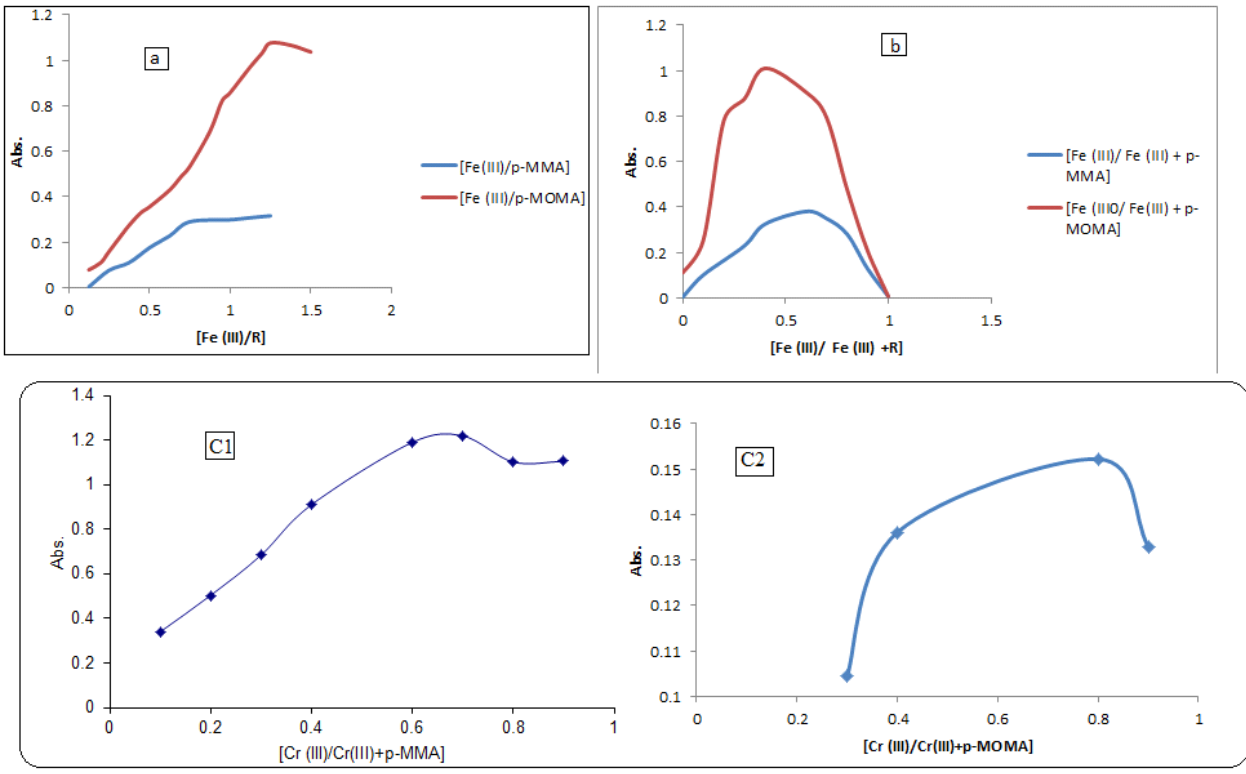

Fig. 4. Stoichiometric ratio of the reaction of Fe (III) and $\mathrm{Cr}$ (III) with indicators by molar ratio and continuous variation under optimum conditions.

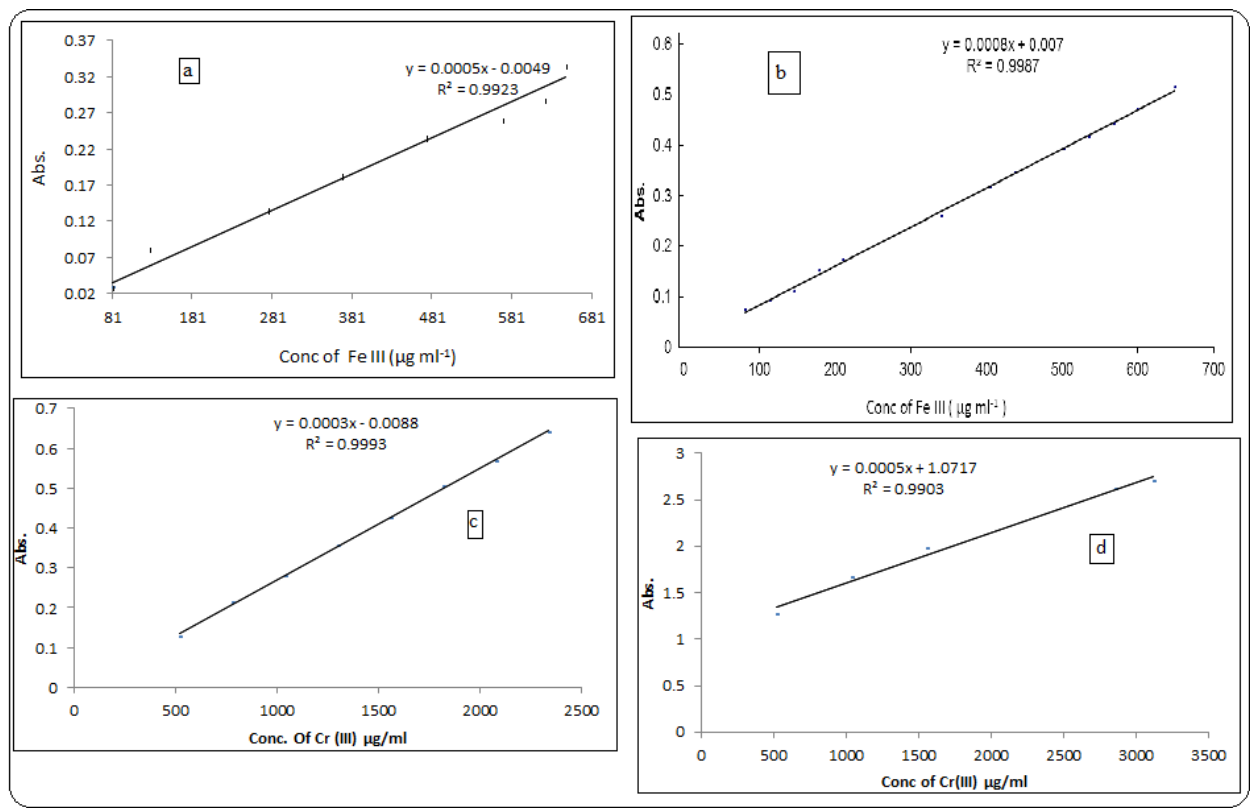

Fig. 5. Calibration curve of 4 X10-2 $\mathrm{M}$ indicators with variable [Fe (III) a, b and Cr (III) c, d] X10-2 M under optimum conditions.

sensitivity, as indicated by the values of SD and $\mathrm{RSD} \%$.

\section{Intraday precision}

In order to prove the validity and applicability of the proposed methods and the reproducibility of the obtained results, four replicate experiments at four concentrations of $\mathrm{Fe}$ (III) and $\mathrm{Cr}$ (III)indicator reaction product were carried out. The spectrophotometric measurements were recorded during Beer's Law is obeyed in the concentration range of 81.10-648.84, 519.50-2337.75, 519.503117.00 and $81.11-648.84 \mu \mathrm{g} \mathrm{mL}^{-1}$ respectively. These data; which obtained of Intraday precision are represented in Tables 4 and 5.

The low values of the calculated standard and relative standard deviation, indicates the high

Egypt. J. Chem. 62, No. 1 (2019) 
TABLE 3. Analytical parameters for spectrophotometric determination of Fe (III) and Cr (III) by using indicators.

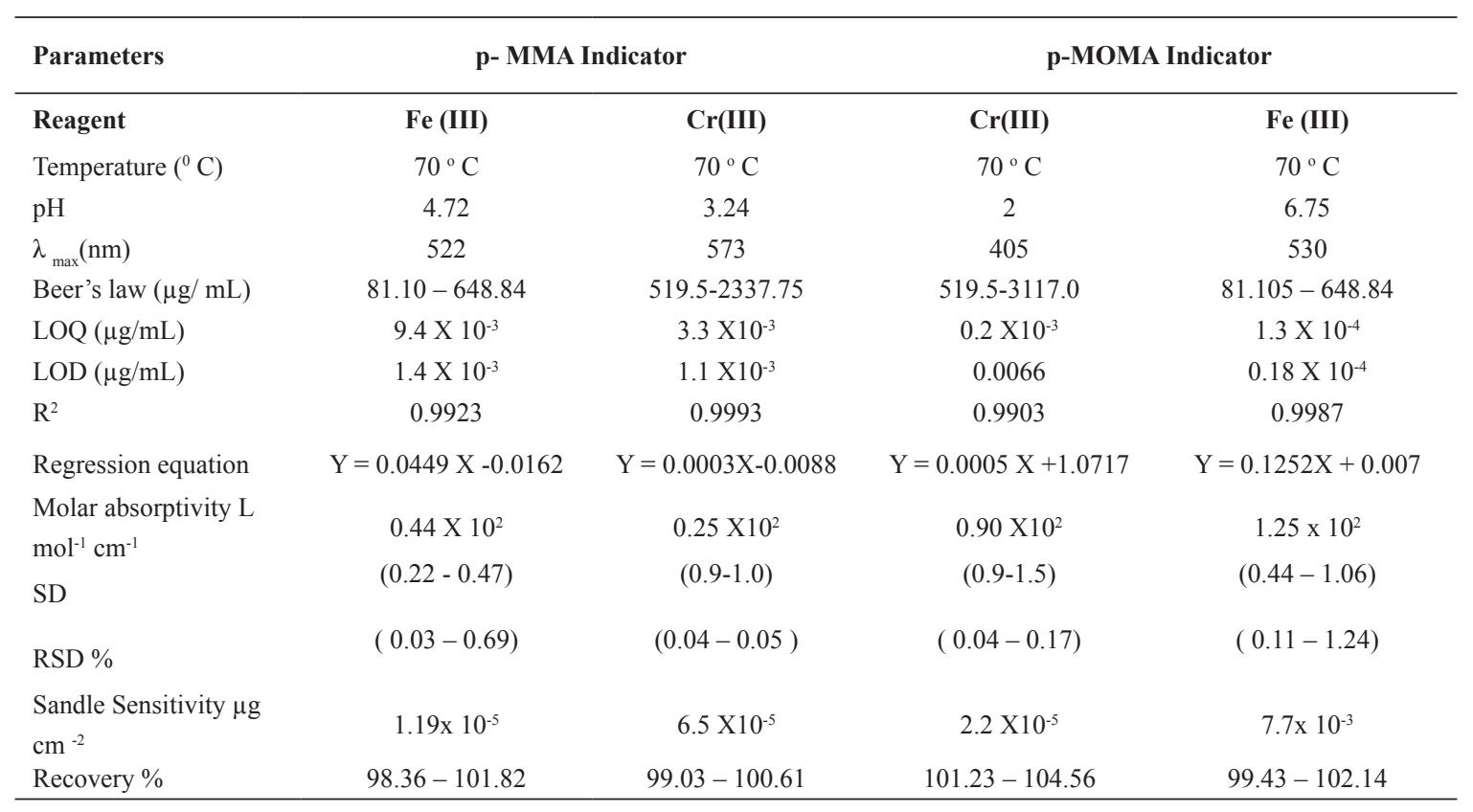

TABLE 4. Within day spectrophotometric micro-determination of Fe (III) by using indicators.

\begin{tabular}{|c|c|c|c|c|c|c|}
\hline \multicolumn{2}{|c|}{$[w t]$ taken $\left(\mu \mathrm{g} \mathrm{mL}^{-1}\right)$} & \multicolumn{2}{|c|}{$[w t]$ found $(\mu \mathrm{g} \mathrm{mL}-1) \pm S D$} & \multirow{2}{*}{$\begin{array}{c}\text { Recovery \% } \\
\text { p-MMA } \\
\text { (p-MOMA) }\end{array}$} & \multirow{2}{*}{$\begin{array}{c}\text { SD }^{\mathbf{a}} \\
\text { p-MMA } \\
\text { (p-MOMA) }\end{array}$} & \multirow{2}{*}{ 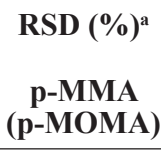 } \\
\hline p-MMA & p-МOMА & p-MMA & p-МOMA & & & \\
\hline 486.63 & 291.978 & $493.75 \pm 0.875$ & $289.27 \pm 0.047$ & $\begin{array}{l}101.55-101.64 \\
(99.08-99.08)\end{array}$ & $\begin{array}{c}0.875 \\
(0.047)\end{array}$ & $\begin{array}{c}0.177 \\
(0.016)\end{array}$ \\
\hline 567.735 & 324.42 & $584.63 \pm 0.625$ & $319.27 \pm 0.141$ & $\begin{array}{c}102.92-103.08 \\
(98.41-98.46)\end{array}$ & $\begin{array}{c}0.625 \\
(0.141)\end{array}$ & $\begin{array}{c}0.107 \\
(0.044)\end{array}$ \\
\hline 616.398 & 405.525 & $626.50 \pm 1.25$ & $405.87 \pm 0.094$ & $\begin{array}{c}101.54-101.80 \\
(100.08-100.11)\end{array}$ & $\begin{array}{c}1.25 \\
(0.094)\end{array}$ & $\begin{array}{c}0.199 \\
(0.023)\end{array}$ \\
\hline 648.84 & 454.188 & $660.38 \pm 0.563$ & $447.20 \pm 0.189$ & $\begin{array}{c}101.73-101.80 \\
(98.46-98.50)\end{array}$ & $\begin{array}{c}0.563 \\
(0.189)\end{array}$ & $\begin{array}{c}0.085 \\
(0.042)\end{array}$ \\
\hline
\end{tabular}

${ }^{\mathrm{a}}$ Mean values for four replicates.

accuracy and precision of the proposed methods.

\section{Study of interferences}

The effect of interference of extraneous cations such as $\mathrm{Cr}$ (VI) and Fe (II) on the accuracy of the proposed procedures applied for microdetermination of $\mathrm{Fe}$ (III) and $\mathrm{Cr}$ (III) in water samples had been estimated. To determine the selectivity of the applied procedures, the solutions of cations under test containing $\mathrm{Cr}$
(VI) and Fe (II) were prepared and analyzed under proper conditions. The obtained results are graphically represented in Fig. 6.

Evidently, $\mathrm{Fe}$ (II) and $\mathrm{Cr}$ (VI) extraneous cations; have the lowest influence on the absorbance of $\mathrm{Cr}$ (III) and Fe (III) (Fig. 6). These results indicate that; $\mathrm{Fe}$ (II) and $\mathrm{Cr}$ (VI) did not interfere with the microdetermination of $\mathrm{Cr}$ (III) and $\mathrm{Fe}$ (III) by spectrophotometric. These results 


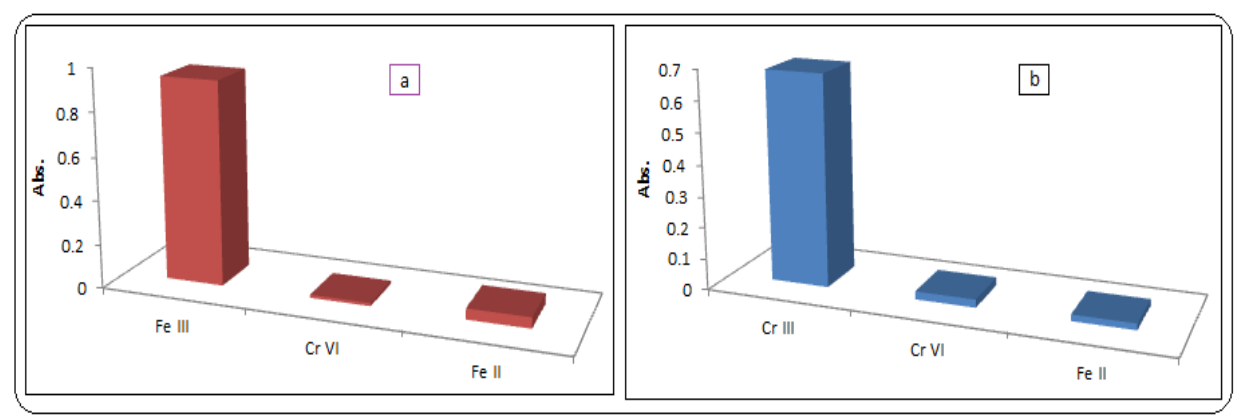

Fig. 6. Effect of the extraneous cations $\mathrm{M}=\mathrm{Cr}$ (VI) and $\mathrm{Fe}$ (II) ions on the analytical signal of a- $\mathrm{Fe}$ (III) and b-Cr (III) respectively (test cation: extraneous cation $M=1: 10$ ).

clearly indicate the high level of selectivity of spectrophotometric procedures using $\mathrm{p}-\mathrm{MMA}$ and p-MOMA indicators, and no masking reagents are required for the successful determination of $\mathrm{Cr}$ (III) and Fe (III) in water samples.

\section{Stability of the color reaction}

The absorbance values of $\mathrm{Fe}$ (III)- and $\mathrm{Cr}$ (III)- indicator reaction are noted at different intervals of time at 522, 530, 573 and $405 \mathrm{~nm}$ respectively. It is observed that, the absorbance remained constant up to 24 hours. Therefore, the color of reaction is stable for at least 24 hours.

Application of the proposed methods to analysis of iron (III) and chromium (III) in water

The developed methods were successfully applied to determine the amount of $\mathrm{Fe}$ (III) and $\mathrm{Cr}$ (III) in wells water samples. The results obtained are shown in Table 6.

These data show that, the proposed spectrophotometric methods are successfully applied for the determined Fe (III) and Cr (III) in wells water samples; which confirmed by high correlation with data obtained by atomic absorption spectrometry. The law concentration values of $\mathrm{Fe}$ (III) and $\mathrm{Cr}$ (III) in wells water samples detected by both proposed spectrophotometric methods and confirmed by atomic spectrometry; refer to the promising possibility of using these underground water wells as potable water sources in villages (Table 1). Therefore; these wells can be used as alternative sources to the River Nile for preparing potable water in these villages.

\section{Biological activity}

The biological activities of p-MMA and p-MOM were determined using a modified KirbyBauer disc diffusion method[34,38]; which were towards two types of bacteria (Escherichia coli (G-) and Staphylococcus aureus $\left(\mathrm{G}^{+}\right)$) and two types of fungus (Aspergillus flavus and Candida

TABLE 5. Within day spectrophotometric micro-determination of $\mathrm{Cr}$ (III) by using indicators.

\begin{tabular}{|c|c|c|c|c|c|c|}
\hline \multicolumn{2}{|c|}{$[w t] \operatorname{taken}\left(\mu \mathrm{g} \mathrm{mL} L^{-1}\right)$} & \multicolumn{2}{|c|}{$[w t]$ found $(\mu \mathrm{g} \mathrm{mL}-1) \pm \mathrm{SD}$} & \multirow{2}{*}{$\begin{array}{c}\text { Recovery \% } \\
\text { p-MMA } \\
\text { (p-MOMA) }\end{array}$} & \multirow{2}{*}{$\begin{array}{c}\text { SD }^{\mathrm{a}} \\
\text { p-MMA } \\
\text { (p-MOMA) }\end{array}$} & \multirow{2}{*}{$\begin{array}{c}\text { RSD (\%) } \\
\text { p-MMA } \\
\text { (p-MOMA) }\end{array}$} \\
\hline p-MMA & р-МОМА & p-MMA & p-МOMA & & & \\
\hline 1558.50 & 519.50 & $1560.07 \pm 0.9$ & $517 \pm 0.9$ & $\begin{array}{c}100.1 \\
(99.51)\end{array}$ & $\begin{array}{c}0.900 \\
(0.900)\end{array}$ & $\begin{array}{l}0.058 \\
(0.174)\end{array}$ \\
\hline 1818.25 & 1558.50 & $1849.67 \pm 1.0$ & $1558 \pm 1.1$ & $\begin{array}{l}101.73 \\
(99.88) \\
\end{array}$ & $\begin{array}{c}1.00 \\
(1.100) \\
\end{array}$ & $\begin{array}{l}0.054 \\
(0.070) \\
\end{array}$ \\
\hline 2078 & 3117.00 & $2040.27 \pm 1.1$ & $3117 \pm 1.5$ & $\begin{array}{l}98.18 \\
(100.0)\end{array}$ & $\begin{array}{c}1.100 \\
(1.500)\end{array}$ & $\begin{array}{l}0.053 \\
(0.048) \\
\end{array}$ \\
\hline 2337.75 & & $2314.93 \pm 1.0$ & & 99.02 & 1.00 & 0.043 \\
\hline
\end{tabular}

${ }^{\mathrm{a}}$ Mean values for four replicates. 
TABLE 6. Comparison between spectrophotometric and atomic absorption used for microdetermination of Fe (III) and $\mathrm{Cr}$ (III) in wells water samples.

\begin{tabular}{|c|c|c|c|c|c|c|}
\hline \multirow{3}{*}{$\begin{array}{c}\text { Well } \\
\text { number }\end{array}$} & \multicolumn{4}{|c|}{$\begin{array}{l}\text { Proposed spectrophotometric methods using indicators } \\
\qquad\left(\mu \mathrm{g} \mathrm{mL} L^{-1}\right)\end{array}$} & \multicolumn{2}{|c|}{$\begin{array}{l}\text { (Atomic Absorption method) } \\
\qquad\left(\mu \mathrm{g} \mathrm{mL}^{-1}\right)\end{array}$} \\
\hline & \multicolumn{2}{|c|}{ p-MMA } & \multicolumn{2}{|c|}{ p-MOMA } & \multirow{2}{*}{$\mathrm{Fe}$ (III) } & \multirow{2}{*}{$\mathrm{Cr}$ (III) } \\
\hline & Fe (III) & $\mathrm{Cr}$ (III) & $\mathrm{Fe}$ (III) & $\mathrm{Cr}$ (III) & & \\
\hline 1 & 170.40 & 156.07 & 170.20 & 156.02 & 170.30 & 156.06 \\
\hline 2 & 130.84 & 184.67 & 130.83 & 183.42 & 129.81 & 184.42 \\
\hline 3 & 200.40 & 204.27 & 200.57 & 204.03 & 199.87 & 204.08 \\
\hline 4 & 130.40 & 231.93 & 130.41 & 230.22 & 129.12 & 231.89 \\
\hline 5 & 130.20 & 284.25 & 130.21 & 285.25 & 130.05 & 285.73 \\
\hline 6 & 100.00 & ------- & 100.00 & ------- & 99.51 & ------ \\
\hline 7 & 120.20 & ------- & 120.21 & ------- & 120.22 & ------ \\
\hline 8 & ------- & ------ & ----- & ------ & 0 & ----- \\
\hline 9 & 240.80 & ------- & 240.81 & ------- & 240.94 & ------ \\
\hline
\end{tabular}

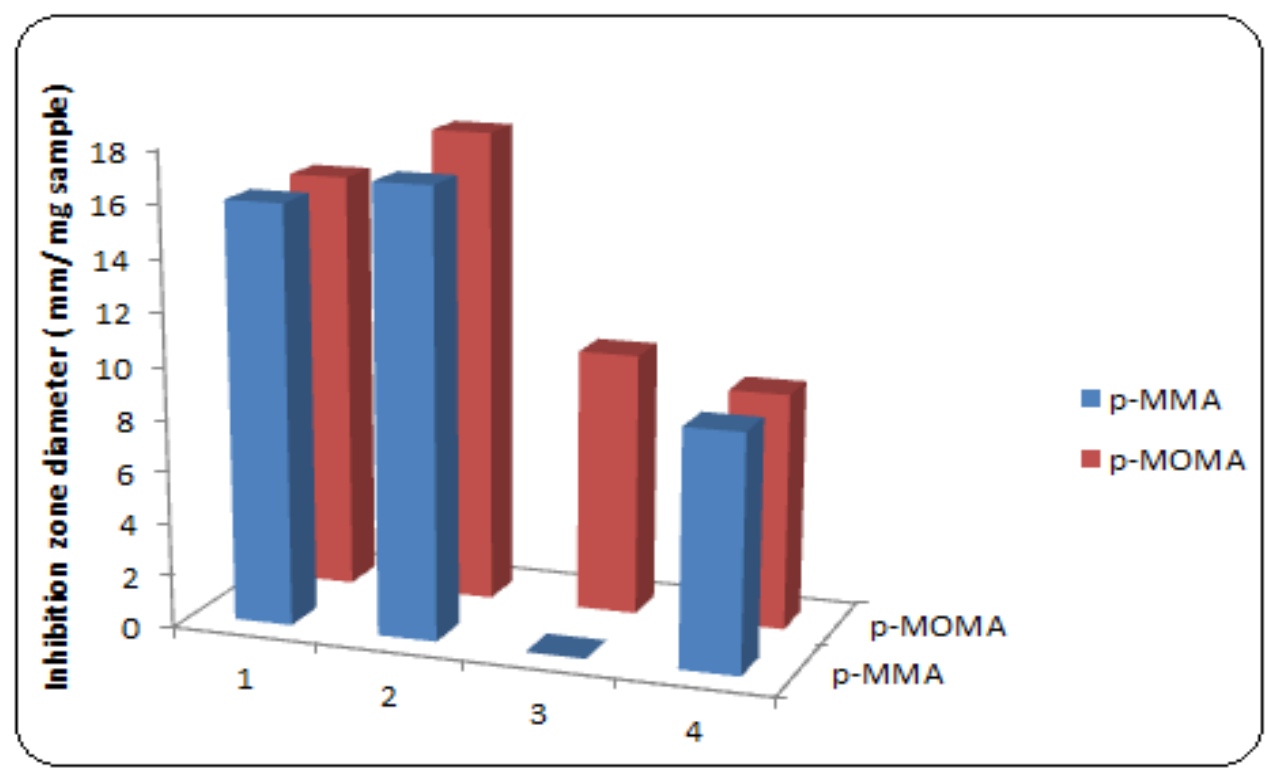

Fig. 7. Antibacterial activities of p-MMA and p-MOMA against (1) pseudomonas aeruginosa (G-), (2) staphylococcus aureus (G+), (3) Aspergillus flavus (fungus) and (4) Candida albicans (fungus).

albicans). Both the antibacterial and antifungal activities were evaluated by measuring the inhibition zone ( $\mathrm{mm} / \mathrm{mg}$ sample). The results are presented in Fig. 7.

Aspergillus flavus (fungus) and (4) Candida albicans (fungus)

These results indicate that, $\mathrm{p}$-MMA and p-MOMA derivatives possess great biological activities towards different kinds of bacteria except Aspergillus flavus (fungus). These compounds showed moderate to weak activity against fungus, but they have high effects for $\left(\mathrm{G}^{+}\right)$ and (G-) because of structure of these indicators containing benzene ring of biologically active substituents like $\mathrm{CH}_{3}$ and $\mathrm{OCH}_{3}$. Therefore; these compounds can be used as chemical probes of protein structure [36], as a protective and curative fungicide [39] and in polymer chemistry as photoinitiators for free-radical polymerization and monomers in polymaleimides or their copolymers synthesis [40, 41].

\section{Cytotoxicity}

Assessment of growth inhibitory effect of p-MMA and p-MOMA on HCT-116 cell, MCF-7 


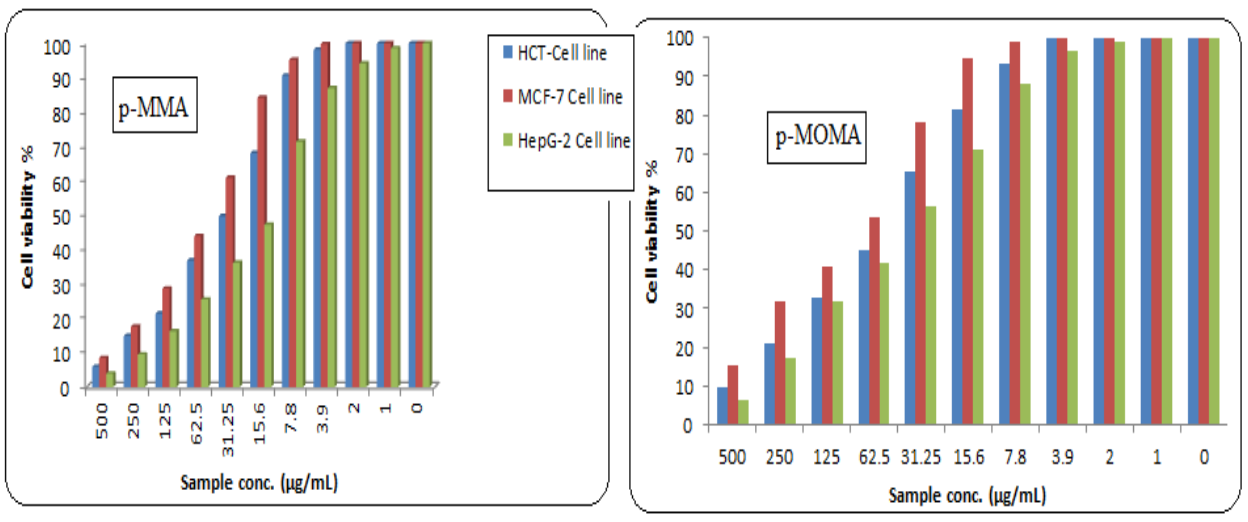

Fig. 8. The effect of p-MMA and p-MOMA on: HCT-116 cell, MCF-7 cell and HepG-2 cell.

cell and HepG-2 cell; in the order of increasing dosages of p-MMA and p-MOMA extract are disruptive against Colon carcinoma cells, Breast carcinoma and Hepatocellular carcinoma. The obtained results are depicted in Fig. 8.

From these results it is clear that:

1- The inhibitory activities of p-MMA and p-MOMA with IC50 values under these experimental conditions against Breast carcinoma cells are detected at 51.3 and $81 \mu \mathrm{g}$ $/ \mathrm{mL}$ respectively.

2- Against Hepatocellular carcinoma cells the inhibitory values are detected at 14.7 and 44.7 $\mu \mathrm{g} / \mathrm{mL}$ respectively;

3- Also against colon carcinoma cells the inhibitory values are detected at 31 and 54.9 $\mu \mathrm{g} / \mathrm{mL}$ respectively.

4- Therefore; p-MMA and p-MOMA are highly effective against Hepatocellular carcinoma cells $>$ colon carcinoma cells $>$ Breast carcinoma cells. It is now recognized, that cancer cells over expression promotes tumorigenic functions; which can be suppressed by p-MMA and p-MOMA inhibitors

\section{Conclusions}

Spectral wells water samples analyses

a. These indicators have always been of great interest; because of their importance and biological activities and method for their preparation is simple, clean, economic and nearly quantative or high yield.

b. Spectrophotometric methods are proposed to determine iron (III) and $\mathrm{Cr}$ (III) using maleanilinic acid derivatives as indicators to these cations in spiked wells underground water samples.

c. The proposed methods are free from common interferences of other extraneous heavy metal cations (Cr (VI) and Fe (II)). These methods are very simple to operate and cost-effective. The accuracy and precision of the methods are tested and agreed well with atomic absorption spectroscopy level.

d. These methods can be used as standard method for determining iron (III) and chromium (III) in any environmental samples.

Anti-Bacterial and Anti-fungi Activity

The obtained results indicate that, the studied the n-substituted maleanilic acids possess a great biological activity towards different kinds of bacteria except Aspergillus flavus (fungus).

\section{Cytotoxicity}

The results obtained of cytotoxicity studies indicate that:

1- Inhibitory activity of p-MMA against Breast carcinoma cells was detected under the experimental conditions and found to be IC50 $=51.3 \mu \mathrm{g} / \mathrm{mL}<$ against Colon carcinoma cells and found to be in the order IC50 $=31 \mu \mathrm{g} /$ $\mathrm{mL}<$ against Hepatocellular carcinoma cells and found to be IC50 $=14.7 \mu \mathrm{g} / \mathrm{mL}$.

2- Inhibitory activity of p-MOMA against Breast carcinoma cells was detected under these experimental conditions and found to be in the order IC50 $=81 \mu \mathrm{g} / \mathrm{mL}<$ against colon carcinoma and found to be in the order IC50 $=54.9 \mu \mathrm{g} / \mathrm{mL}<$ Inhibitory activity against Hepatocellular carcinoma and found to be IC50 $=44.7 \mu \mathrm{g} / \mathrm{mL}$. 
3- Therefore; p-MMA and p-MOMA are highly effective against cancer cells in the following order: Hepatocellular carcinoma cells $>$ colon carcinoma cells $>$ Breast carcinoma cells.

\section{Acknowledgments}

The authors acknowledge the supports presented by ministry of military production Laboratories, Chemistry Department, Faculty of Science, Cairo University and Water Company in Kom Hamada City in the El-Beheira Governorate, Egypt.

\section{References}

1. Sigel, A.; Sigel, H.; Sigel, R.K.O., Metal Ions in life Science. Wiley Chi Chester, Vol.1 (2006).

2. Gunnar Nordberg; Bruce Fowler; Monica Nordberg, Handbook on The Toxicology of Metals, 4th ed.; Amsterdam, Elsevier, 2014, Chapter 41, Iron. pp 879-902.Website http://dx.doi.org/10.1016/B9780-444-59453-2.00041 (accessed October 20, 2017)

3. Pérez-Urquiza, M.; Beltrán, J.L., Determination of the dissociation constants of sulfonated azo dyes by capillary zone electrophoresis and spectrophotometry methods, 917, 331-336 (2001).

4. Saeidi, M.; Aboutalebi, R.; Darehkordi, A., A new spectrophotometric reagent for $\mathrm{Fe}(\mathrm{III})$, 2-(2,3-dihydroxy-4-oxocyclobut-2-enylidene) hydrazinecarbothioamide and its application in real samples. J. Chem. 1-6 (2013).

5. Vemula M.; Prasad, T.N.V.K.V.; Gajulapalle M., Synthesis and spectral characterization of iron based micro and nanoparticles, Iran. J. Energy Environ 4 (4), 385-390 (2013).

6. Sun, Y.P.; Li, X.; Cao, J.; Zhang, W.; Wang, H.P., Characterization of zero-valent iron nanoparticles, Adv. Colloid Interf. Sci. 120, 47-56 (2006).

7. Kumar, B.; Smita, K.; Cumbal, L.; Debut, A., Biogenic synthesis of iron oxide nanoparticles for 2-arylbenzimidazole fabrication, J. Saudi Chem. Soc. 18 (4), 364-369 (2014).

8. Pattanayak, M.; Mohapatra, D.; Nayak, P.L., Green synthesis and characterization of zero valent iron nanoparticles from the leaf extract of Syzygium aromaticum (clove), Middle-East J. Sci. Res. 18 (5), 623-626 (2013).

9. Chen, P.C., Gold nanoparticles: From nanomedicine to nanosensing, Nanotechnol. Sci. Appl. 1, 45-55 (2008).

Egypt. J. Chem. 62, No. 1 (2019)
10. Cheng, Z.; Zaki, A.; Tsourkas, A., Multifunctional nanoparticles: cost versus benefit of adding targeting and imaging capabilities, Science 338, 903-910 (2012).

11. De Jong, W.H.; Borm, P.J., Drug delivery and nanoparticles: Applications and hazards, Int. J. Nanomedicine 3 (2) 133-149 (2008).

12. Talbot, C.M., Spectroscopic Characterization of Nanoparticles for Potential Drug Discovery, Shimadzu Scientific Efforts Current Research, first ed. (2014).

13. Eller, P.C.H.; Haastrup, S., Preparation and characterization of metal nanoparticles, Fagprojekt - Fysik og Nanoteknologi Danmarks Tekniske Universitet (2011).

14. Okitsu, K., UV-Vis Spectroscopy for Characterization of Metal Nanoparticles Formed from Reduction of Metal Ions During Ultrasonic Irradiation, Chapter UV-VIS and Photoluminescence Spectroscopy for Nanomaterials Characterization, 15, Springer Berlin Heidelberg, 151-177 Print ISBN 978-3642-27593-7 (2013).

15. Barreca, D.; Carraro, G.; Devi, A.; Fois, E.; Gasparotto, A.; Seraglia, R.; Maccato, C.; Sada, C.; Tabacchi, G.; Tondello, E.; Venzo, A.; Winter, M., $\mathrm{b}-\mathrm{Fe}_{2} \mathrm{O}_{3}$ nanomaterials from an iron(II) diketonatediamine complex: a study from molecular precursor to growth process, Dalton Trans. 41, 149 (2012).

16. Fawell, J.K.; Land, U.; Mintz, B.; Iron in Drinking water. Back ground document for development of WHO Guidelines for Drinking Water Quality. (online).http://www.who.int/water_sanitation_ health/dwq/chemicals/iron.pdf (accessed on October 9 , 2017).

17. International Organization for Standardization, Water quality - determination of iron. http://www. iso.org/standards/12630.htm. (accessed on October 9, 2017).

18. Kotas, J.; Stasicka, Z.; Chromium occurrence in the environment and methods of its speciation. Environ Pollut. 107-263 (2000).

19. U.S. EPA. Ground Water and Drinking Water: National Primary Drinking Water Regulations. Website, https://www.epa.gov/ground-water-anddrinking-water/national-primary-drinking-waterregulations (accessed on October 12, 2017).

20. Saedi, H., Solvent free preparation of N-substituted maleanilic acid, Bull. Chem. Soc. Ethiop. 27(1), 
137 (2013).

21. Abdel-Shafy, H.I., Aziza H. Kamel., Groundwater in Egypt Issue: Resources, Location, Amount, Contamination, Protection, Renewal, Future Overview, Egypt. J. Chem. 59 (3), 321- 362 (2016).

22. Zayed, M. A.; Elhdad, A.M., Quality evaluation of ground water for drinking and irrigation purposes in Beheira governorate, European Academic Research, IV (5), 4687-4706 (2016).

23. Zayed, M. A.; Elhdad A.M.A., Assessment of Groundwater Pollution with Heavy Metals based on Pollution Index and Investigation of Groundwater Quality Using Water Quality Index in Western Nile Delta, Egypt. International Journal of Scientific Engineering and Research (IJSER) 5 (9) 24-35 (2017).

24. Zayed, M. A., Elhdad, A.M. A., Hydro Chemical Facies and Ionic Ratios of Ground Water in Kom Hamada City, Beheira Governorate (Western Nile Delta), Egypt. Journal of Water Research 138, 300-325 (2017).

25. Zayed, M.A.; Mahmoud Farouk., The Use of Diphenylamine Sulfonate Redox Indicator in Spectrophotometric Micro-determination of NonSteroidal Anti-Inflammatory Drugs Egypt.J.Chem. 60 (6), 1135-1149 (2017). DOI: 10.21608/ EJCHEM.2017.1560.1120

26. Zayed, M.A.; Manal. A. El-Shall; Marwa. A. Abdallh, Spectrophotometric Determination of Fluconazole, Voriconazole and Butoconazole nitrate by Ion-Pair Formation with Rose Bengal Reagent. Egypt. J. Chem. 60 (6), 1177-1188 (2017). DOI: 10.21608/EJCHEM.2017.1299.1075

27. Zayed, M.A.; Abdel-Basset, M.H. Spectrophotometric Micro-Determination of Tretinoin, Isotretinoin and Tazarotene via Reactions with Iodine or Rose-Bengal Reagents, Egypt.. J. Chem. 61 (1), 143-153 (2018). DOI: 10.21608/EJCHEM.2017.1741.1147

28. Mosmann, T., Rapid colorimetric assay for cellular growth and survival: application to proliferation and cytotoxicity assays. J. Immunol. Methods $\mathbf{6 5}$, 55-63 (1983).

29. Gomha, S.M.; Riyadh, S.M.; Mahmmoud, E.A.; Elaasser, M.M., Synthesis and Anticancer Activities of Thiazoles, 1,3-Thiazines, and Thiazolidine Using Chitosan-GraftedPoly(vinylpyridine) as Basic Catalyst. Heterocycles, 91(6), 1227-1243 (2015).
30. Britton, H. T. S., Hydrogen Ions, $4^{\text {th }}$ edition, Chapman and Hall, London (1952).

31. Vosburgh, W. C.; Cooper, G. R., Complex IonsI- The Identification of Complex Ions in Solution by Spectrophotometric Measurements, J Am Chem Soc. 63 (2), 437-442 (1941).

32. Yoe, J. H.; Jones A. L., Colorimetric Determination of Fe with Disodium 1, 2- Dihydroxybenzene-3, 5 Disulfonate. Ind Eng Chem Anal Ed, 16 (2), 111115 (1944).

33. National Field Manual for the Collection of WaterQuality Data, U.S. Geological Survey TWRI, Book 9 Chapter A4, version 2.0,9 (2006).

34. Bauer, A.W.; Kirby W.M.; Sherrius, C.; Turck.M., Antibiotic susceptibility testing by a standardized single disc method, American Journal of Clinical Pathology, 45, 493-496 (1966).

35. National Committee for Clinical Laboratory Standarda, NCCLS Approval Standard Document M2-A7, Vilanva, PA, (2000).

36. Corrie J.E.T.J., Thiol-reactive fluorescent probes for protein labeling, Chem. Soc. Perkin Trans. I 2975-2982 (1994).

37. Sakiyan, I.; Logoglu, E.; Arslan, S.; Sari, N., Antimicrobial activities of N-(2-hydroxy-1naphthalidene)-amino acid (glycine, alanine, phenylalanine, histidine, tryptophane) Schiff bases and their manganese (III). Biom 17, 115-120 (2004).

38. Rahman, M.I.; Choudhary, W.J., Thomsen Bioassay Techniques for Drug Development, Harwood Academic Publishers, The Netherlands, 16 (2001).

39. Fujinami, A.; Ozaki, T.; Nodera, K.; Tanaka, K. Agric., Studies on Biological Activity of Cyclic Imide Compounds, Part II. Antimicrobial Activity of 1-Phenylpyrrolidine-2,5-diones and Related Compounds, Biol. Chem. 36, 318

40. Rodolfo, A.; Valencia H.; Pardo, Z.D.; Vriesa, R.; Kennedy, A. R. A, N-(3-Nitrophenyl) maleimide, Acta Cryst. 62, 2734-2735 (2006).

41. Jenkins, J.D.; Musayev, F.N.; Danso-Danquah, R., Abrahamand, D.J., Safo, M.K., Structure of relaxed-state human hemoglobin: insight into ligand uptake, transport and release, Acta Cryst. D65, 41-48 (2009).

(Received 12/7/2018; accepted 10/9/2018) 


\section{استخدام مشتقات حمض المالينيلك لتحليل عينات مياه الآبار الأقليمية ودر اسـات بيئية باستخدام

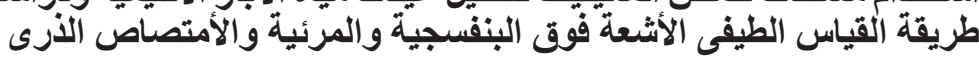

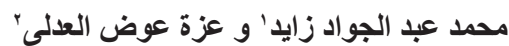

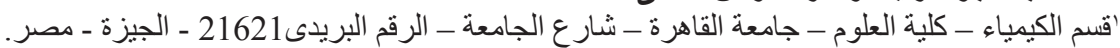 זمركز التميز العلمي و التكنولوجي- وزارة الأنتاج الحربي ـ مدينة السلام ـ القاهرة ـ مصرة.}

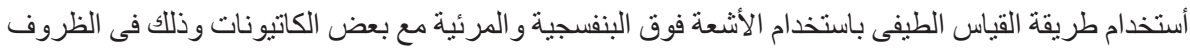

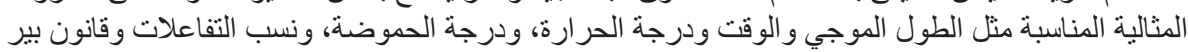

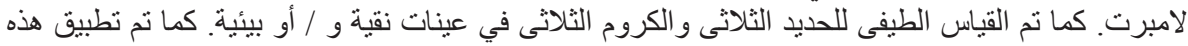

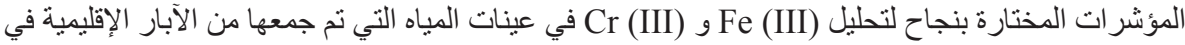

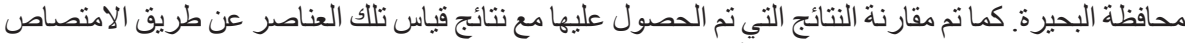

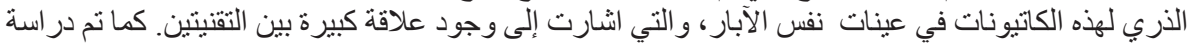

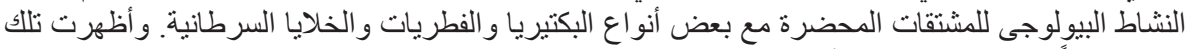

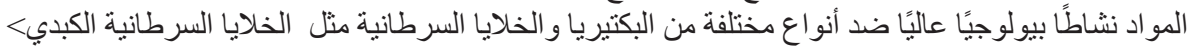

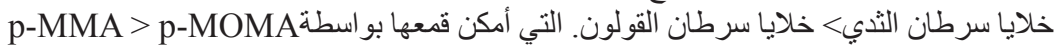

